\title{
Poetic Manifestos and Democracy (in Poland after 1989)
}

Abstract: Hoffmann Krzysztof, Poetic Manifestos and Democracy (in Poland after 1989). "Poznańskie Studia Slawistyczne" 17. Poznań 2019. Publishing House of the Poznań Society for the Advancement of the Arts and Sciences, Adam Mickiewicz University, pp. 75-86. ISSN 2084-3011.

A form of poetic manifesto rooted in the avant-garde tradition is construed here as a performative project of the future. This temporal quality links it with the Derridean notion of "democracy to-come". The presented paper attempts to trace an (im)possible connection between poetic manifestos and democracy in Poland after 1989. In pursuance of this objective, the paper briefly presents the only four 21 st-century Polish manifestos that attracted some critical and/or artistic attention: Meblowanie główww, Manifest Neolingwistyczny v. 1.1, Manifest poezji cybernetycznej and Manifest Rozdzielczości Chleba v. 1.7.

KeYwords: manifesto; democracy; Polish literature after 1989; neolinguism; avant-garde

\section{Prolepsis and promise - affiliations and symmetries}

The kinship of poetic manifesto and democracy might not be evident at first glance, it might be elusive even at the second. On the one hand, the form in question is a strongly idiomatic and idiosyncratic declaration that is saturated with performativity and, more often than not, bears an exclusive gesture based on the radical and strong demarcation of a border. On the other hand, democracy forces one to be confronted with a model of discourse that is intentionally and overtly inclusive, a model that strives to account for all differences - not to dialectically sublate them but to think all differences in a potential realm where they co-exist in an abundance of mutual tensions. Nevertheless, such opposition is valid only as long as one considers the manifesto as a violent attempt to establish a new, always 
singular law, while democracy is perceived in the spirit of a Kantian regulative idea.

There is, however, another way to construe democracy. It was proposed by Jacques Derrida - for the first time in the 1990 book, Du droit à la philosophie, and later it was developed in his subsequent writings. It is a democracy of what is to-come, démocratie à venir. Democracy to-come is not an imperative modality of citizen interpellation but should be an event, which is first and foremost prepared in the dimension of temporality. In 1991, Derrida wrote that it is a way of thinking "not something that is certain to happen tomorrow, not the democracy (national or international, state or trans-state) of the future, but a democracy that must have the structure of a promise - and thus the memory of that which carries the future, the to-come, here and now" (Derrida, 1992, 78). Disrupting the horizon which carries itself away, horizon of a constantly vanishing future democracy to-come is a call from the future, the appeal to constantly reconfigure our present. Only this way, a future impossible to predict, to program, to schedule, i.e. future as l'avenir, can happen. Hence, democracy is understood here no longer as a project but as an event, not the idea of future, but the future of idea.

This temporal structure is what affiliates democracy with manifesto and, at the same time, what symmetrically opposes them. The latter also engages future / here-and-now dialectics but involves a different polarization of the opposition and resorts to aggressive rhetorical devices.

One can find the aforementioned relationship in the very roots of manifesto, which - as Laura Winkiel observes - require a necessity of political project. Throughout this paper the model of manifesto is found in the manifestos of historical avant-garde movements, but for Winkiel the "basic structure" of manifesto, had been revealed even earlier, during the Enlightenment revolutions. It is based on a "declaration of a break from history understood as a repetition of the same". Moreover, political manifesto had a democratic trait as it meant introduction of le peuple in place of bourgeois citoyen, it "declared a break from bourgeois history in order to claim a space within public sphere so as to lead society in radically new directions" (Winkiel, 2015, 253). In his book Poetry and the Revolution: Marx, Manifestos and the Avant-Gardes, Martin Puchner used the speech act theory to identify the fundamental manifesto aporia: it aims to gain 
agency and to effect in significant change by a pure document; however, it can achieve it only by resorting to theatrical and performative devices which have to assume their future efficacy. This is why the figure of manifesto is prolepsis, speaking in future perfect tense (cf. Puchner, 2006). It is necessary for the manifesto to establish its own future validity or - as Winkiel comments - "Manifestos suggestively enact the future they want to produce" (Winkiel, 2015, 255).

Such speculation, in which the promise of democracy to-come and the proleptic literary manifesto share some structural similarities, encourages us to ask a question about actual historical artifacts. The quoted passage from Derrida was initially presented at a lecture held in May 1990 and appeared later in his book under a telling title, The other heading. The philosopher proposed taking the other course, the one of démocratie à venir, in reaction to "what has started or rather has accelerated, these past few months in the east or at the center of Europe" (Derrida, 1992, 17). One might expect that changes in the Polish political system after 1989 resulted in some radical freedom projects, that culture, finally liberated, started to proclaim utopias of the future. In other words, one could suppose, that the last 30 years of Polish literature and especially its manifestos, regarded from the contemporary perspective, shed retroactive light on an imagined democracy. The story is, however, much more complicated.

\section{Manifestations of no manifestos}

Among the most characteristic features of the first decade in free Poland, one can find the plain programmatic lack of aesthetic or political poetic programs. Not only no poetic manifesto was written at that time, but, moreover, a poetic generation that took its turn to speak, the so-called "bruLion" generation, clearly proclaimed political and ideological désintéressement.

The fact that there was no manifesto of pure genre, i.e. there was no single text expressing program with reference to the avant-garde rhetoric, does not mean that there were no texts read as programmatic statements. One of the most famous is definitely a poem by the most prominent 
"bruLion" poets, Marcin Świetlicki, For Jan Polkowski. Written in 1988, delivered in 1989, it was published in 1992, and for a long time, it shaped despite the author's reluctance - the discussion on the poetry of the 1990s. It was considered to be one of the most explicit outright refusals to adjust to the poetic voice set by older writers. Jan Polkowski (born 1953), to whom the text in question is addressed, is a poet and democratic opposition activist, interned during the martial law. In the poem by Świetlicki (born 1961), Polkowski becomes the embodiment of diction subservient to a greater cause, hence appropriated by the idea of poetry that in a blasphemous manner is defined as "poetry of slaves":

The poetry of slaves lives on ideas, / and ideas are a watery substitute for blood. / The heroes remain imprisoned, / and the worker is ugly but touchingly / useful - in the poetry of slaves. [...] Instead of saying: I have a toothache, I'm / hungry, I'm lonely, both of us, four of / us, our whole street-hey say quietly: Wanda / Wasilewska, Cyprian Kamil Norwid, / Jozef Pilsudski, the Ukraine, Lithuania, / Thomas Mann, the Bible, and at the end a little something / in Yiddish (transl. by William Martin; Świetlicki, 2000, 278-289).

Although between the attacker and the attacked there is only 8 years of age difference, the rhetorical chasm opened by this poetic gesture is unbridgeable and it was read as a declaration of the generation gap. The poetry that is seeking support in literary tradition, historical traumas and national heroes is confronted by Świetlicki with a private experience of individual that is non-negotiable in shared idiom. The symbolic is replaced by the somatic, the political makes room for the personal.

When another older poet and literary critic, Julian Kornhauser, accused the "bruLion" poets of negligence of ideology, they responded in 1993 with a poem addressed directly to him. Three authors with the same name, that is, Marcin Świetlicki, Marcin Sendecki, and Marcin Baran published Wiersz wspólny (pólfinałowy) (A Collective Poem [semifinal]):

We would write poems / full of pretty good ideas / or any ideas. / But, dear Julian, / there is none out there, / Yeah, out there not a fuck of ideas

(own translation; Napisalibyśmy wiersze / pełne niezłych idei / lub jakichkolwiek. / Ale, drogi Julianie, / żadna nie stoi za oknem. / Tak, za oknem ni chuja idei; Baran, Sendecki, Świetlicki, 1993, 79). 
The poem For Jan Polkowski turned out to be an overly clear declaration, which too easily encapsulated the post-1989 poets in a few handy phrases. It is enough to say that Świetlicki, who in many different ways strove to weaken the poem's aftermath, also struggled to be more than a single piece author. But the milk was spilled. The "bruLion" poets were acclaimed to be poets whose program is devoid of ideological-political contents, and it was perceived as being focused on personal experience in order to proclaim the new everyday republic instead of a new republic every day.

The aforementioned poems were read as manifestos, but the manifesto genre was not in use. One of the reasons for such a situation might have been related to the strong impact of the older poets. The Generation '68 poets, the poets of the so-called New Wave (Stanisław Barańczak, Julian Kornhauser, Ryszard Krynicki, Adam Zagajewski and others), did both: expressed themselves via manifestos and explicitly stated the necessity of poetry political involvement. In response, after 1989, the manifesto was treated not only with suspiciousness, but also with a complete lack of trust. It is telling that Agnieszka Śliz in her research on literary manifestos in the $20^{\text {th }}$ century Poland chooses about 40 of the most important manifestos, but only one written after 1989 (from 2002 to be precise). Although Śliz claims that this manifesto obliteration is connected "with lesser importance and activity of literary or artistic groups" (Śliz, 2015,142 ), one may suspect that such a sociological explanation misses the point. The manifesto became an obsolete genre because discourse and communication conditions underwent a radical change. In order to be valid, each manifesto has to believe in its own performative authority and its proleptic play with temporality. Meanwhile it was as Francis Fukuyama's thesis on the end of history (quoted more often than it deserved; published in a book form in 1992 but - this confluence is worth remembering - basing on the 1989 essay; cf. Fukuyama 1992) made impossible the very chance of temporal thinking in manifesto modality. The manifesto became not a vehicle of change but a genre convention, which can only be pastiched at the very best (but in the last decade of $20^{\text {th }}$ century, there were no manifesto pastiches either). 


\section{Four manifestos from the $21^{\text {st }}$ century}

One can observe problems with a trust in manifesto by tracing the history of the (relatively) most well-known Polish poetic manifesto from the $21^{\text {st }}$ century. All of them are short documents - also in terms of their lifespan. The texts in question are: the already mentioned statement from 2002, Manifest Neolingwistyczny v. 1.1 (Neolinguistic Manifesto v. 1.1). Along with Manifest poezji cybernetycznej (Cybernetic Poetry Manifesto) (2006) and Manifest Rozdzielczości chleba v. 1.7 (The Bread Resolution Manifesto v. 1.7) (2011), it composes the modest landscape of $21^{\text {st }}$ century Polish literature manifestos.

To be precise, there was also the manifesto of "Meble" (Furniture) journal, entitled Meblowanie główww (Furnishing headdds) (2001), ${ }^{1}$ but it was to a large extent devoted to the journal design. The authors (Anna Krauss, Jarosław Lipszyc, Maria Cyranowicz, Wojtek Pakier, Agnieszka Słodownik, Radek Dutkowski, 2005, 123-124) claimed: "Literary journals guard the form and content separation. They isolate graphics in 'gallery' sections. They consider it as a text ornament. Most often it is placed only on covers. MEBLE refer to the avant-garde tradition." The last sentence is telling here, but, contrary to the tradition, the journal program was aware of its faint agency. One can notice it in paradoxes that ironically undercut the very possibility of manifesto:

Why do all literary journals LOOK THE SAME? We don't know. MEBLE looks terrible too. [...] Why do all literary journals WRITE ABOUT THE SAME THING? They have no ideas. And no one will look into MEBLE anyway. [...] Why PEOPLE DON'T READ literary journals? Because they are boring. Just as MEBLE (Cyranowicz, Dutkowski, Krauss, Lipszyc, Pakier, Słodownik, 2005, 123-124).

Therefore, the proper manifesto of the literary group did not appear until 2002. It was Manifest Neolingwistyczny v. 1.1 published simultaneously online and in the first issue of "LiteRacje". What is important is that a part of signatories is already known; the manifesto was signed by: Marcin Cecko, Maria Cyranowicz, Michał Kasprzak, Jarosław Lipszyc and Joanna Mueller. The neolinguists preached in the avant-garde spirit:

${ }^{1}$ It was handed to audience during a panel discussion entitled "Transformation of culture" (7.11.2001, "Warszawa Pisarzy" Festival). 
"Milk has boiled over; the banner has fluttered off. We are not poets. We send to hell diary poems, song poems, poems that are different from life only thanks to the diarrhea of 'return' button presses. Time has liberated words once again. We send poems to hell. There is text" (Cyranowicz, 2005, 158). Poets referred thus to Wittgenstein, constructivism and poststructural textualism. They applied the digital technology metaphors and stated: "We announce the death of paper [...] we choose screen" (Cyranowicz, 2005, 158). The text attracted critics' attention; it is hard to be surprised - the authors (almost correctly) emphasized that "Polish poets have not published any manifesto since the New Wave" (Cyranowicz, 2005, 158).

Nevertheless, although neolinguism had managed to achieve relative success, what is more interesting is that the authors immediately started to undermine the import of their program text. Joanna Mueller in the neolinguistic movement anthology stated overtly that "the whole neolinguistic turmoil was a fairytale, by which [...] a few suckers got tricked" and declared: "So we pack up, we pack up, and by the way one has to do a self-critique. As I too was the first one to be taken in by the manifesto joke" (Mueller, 2005, 8). The fact that the manifesto which was a pastiche of avant-garde dictions was itself pastiched, confirms that manifesto has ceased to be a literary weapon: Michał Kasprzak (2005, 9-10) announced Nekrofest Postneolingwistyczny (Postneolinguistic Necrofesto). Furthermore, Kuba Głuszak and Jaś Kapela (2005, 170-171) made a parody entitled Manifest Protodupistyczny (Manifesto Proto'ass'istic).

The only program that was written in the form of manifesto and is to some extent still valid (the fact which one should consider rather as an exception to the rule) appeared in the borderline area between literature and new media. Initially there was the Manifest poezji cybernetycznej signed by Roman Bromboszcz, Marek Florek, Szczepan Kopyt, Tomasz Misiak and Lukasz Podgórni. The poets referred to scientifically understood cybernetics and preached scientization of literature:

So-called 'inspiration' shifts to a background and sometimes vanishes completely. Systematic reconstruction and destruction of already existing word matter eliminates habit as well as style. Statistics and the theory of information, collage and montage, the future forms (Bromboszcz, Florek, Kopyt, Musiak, Podgórni, 2007, 42). 
Thus, literary theory terms were replaced by such notions as: feedback loop, information, code, signal, noise. Still, even this positive program did not stand the test of time. Cybernetic poets have never become an influential community, they have not produced important works and today the most easily recognizable one, Szczepan Kopyt, does not stop in efforts not to be associated with the group.

The idea was continued by Rozdzielczość Chleba - a collective and a "patainstitution" that publishes almost exclusively on the Internet (on the site with inventive address, ść-ch.pl). The name of the group and the journal is a multilevel pun. A direct English equivalent of rozdzielczość is resolution (so "The Bread Resolution"), but it is also very close to rozdzielnictwo, that is, distribution ("The Bread Distribution"). The ear of Polish native speaker brought up in the Catholic context can also easily catch the echo of rozmnozenie chleba i ryb (the multiplication of loaves and fish), performed by Jesus and recounted in John 6:1-15 (hence it is also "The Bread Multiplication"). Resolution would refer to electronic/new media qualities of literary works, distribution and multiplication to the collective character of the group's actions and projects.

Their 2011 manifesto ("produced" by Leszek Onak and Łukasz Podgórni and also signed by Roman Bromboszcz, Piotr Puldzian Płucienniczak and Tomasz Pułka) is the only somehow valid Polish literary manifesto. The Bread Resolution claims that

The text hang-up is because of paper - the function of the Internet is interaction and motion [...]. Omnipresent wi-fi, like God, projects our enterprises blinking with the sum of holy diodes. [...] Let's digitalize the guts of libraries and let's burn them down [...]. Print screen is a new stylistic device! Cleverbot for president!" (Onak, Podgórni, 2011, 4-6).

However, one can see ambivalence even here. The Bread Resolution seeks for revival of literature in the death of a traditional literature institution. The group introduces into the text non-human factors (drawing heavily on glitch aesthetics). In 2015 they published Metamanifest cyberżulerstwa (Cyberbumming Metamanifesto) which, in their opinion, indicated the end of fascination with the Internet and cyberpoetry (Płucienniczak, Podgórni, Onak, 2015, 38-55), and a shift towards the awareness of enslavement by power - be it the power of men and/or the power of machine. Still today, 
it is the only active literary group with the manifesto in its achievements. (Or rather it was one). ${ }^{2}$

\section{Exhaustion of manifesto?}

Against structural similitude between the project of democracy-tocome and a chance created for and by a manifesto, the democracy that actually came after 1989 did not encourage poets to pursue some radical gestures. The manifesto became exhausted (at least in the literary reality that we are familiar with).

Przemysław Czapliński is right when he claims that - if literary productions verify the poetics postulated by any manifesto - literary critical debate is a similar test: this time in the field of literary life (Czapliński, 1992, 68). Nevertheless, in the critical theater there is space only for those manifesto performative statements that effectively establish facts, i.e. that believe in their own proleptic power.

Yet, the only manifesto that elicited any significant critical response after 1989 was Manifest Neolingwistyczny - the same manifesto that dealt mainly with ironic undercutting of its own agency. This fact was aptly noticed by Barbara Sienkiewicz who wrote in this context:

Poetry is thus engulfed not by the element of dialogue - as Manifesto claims - but of paralogy. [...] A poem formed out of words referring to genetically diverse discourses has the structure of drama only on the surface; if it becomes "the theater of the speech", it is indeed "the theater of the absurd" in which inter-words communication is not possible. Because the sense is cancelled in the very moment of its establishment (Sienkiewicz, 2007, 587).

A manifesto which withdraws its own meaning as soon as it commences to emerge cannot constitute any project of a future. Although the critics

${ }^{2}$ The paper was written in Spring 2018. When I was submitting it to the journal in Fall 2018, I visited the aforementioned website. In yet another obituary the group declared: "In Fall 2018 we decided it's time to pack up and look for new forms of activity." https://rozdzielchleb.pl/o-nas/. 13.06.2019. For a more exhaustive commentary on Rozdzielczość chleba and on Cyberbumming Metamanifesto, cf. Kotuła, 2018. Kotuła's paper was written after the group announced its end. 
perceived the relationship between the neolinguism and the deconstruction, from the historical point of view this affiliation turned out to be related only to the fact of taking part in the (more or less) same cultural moment. In other words, this relationship was not a result of the co-creation of axiological sphere (Sienkiewicz, 2007, 587).

For Derrida, the future to-come, the future of democracy that we are unfamiliar with yet, has to interact on the present. The fact of sharing with democracy some elements of the structure of a promise means for manifesto the necessity of unceasing interventions in the tissue of the present, a production of awaiting. The historians of literature underscore this interrelation when they observe the seriality of historical avant-garde manifestos and stress "the fact that a manifesto rarely is a singular text" (Gazda, 1987, 86). Polish literary manifestos after 1989 did not form any series or sequence (the only exception was the case of cyberpoets) - they were only able to immediately evoke parodies.

From the history of ideas position, one should claim that, if manifesto activity might testify for being moved by Derridean thought about requirement of speculative vitality in the awaiting for an event, the Polish artists' strategy situates itself closer to the Fukuyama's stagnation - the end of history and of future. Still, one can take a viewpoint of literature itself. The last sentence from the book on Polish literary manifestos (what is important is the fact that it is on the interwar period; the same book about the present times could not be written) is quite telling: "The real end of literary manifesto will not come until the day, when no one will argue about the reasons of literature's existence" (Czapliński, 1997, 207). What remains is a rhetorical question: what are these reasons today?

Polish manifestos did not articulate a proleptic prophecy. Their condition is rather similar to the discourse behind Julian Rosefeldt's work from 2015, Manifesto. The artist created a multi-screen film installation, in which he composed excerpts from historical manifestos - starting with Manifesto of the Communist Party, through futurism, suprematism, situationism up to Dogme 95. All collages are performed by Cate Blanchett who plays 13 different roles. In one of the segments, she delivers a Tristan Tzara's manifesto from 1918 - she performs it as a funeral speech, surrounded by mourners. A witty and comic juxtaposition of dada sacrileges and profanities with, nomen omen, grave face expressions and dead silence 
of the mourners has subversive potency but, at the same time, it is a funeral of manifesto. The manifesto language has become recognizable stereotypical convention and citable cliché easy to graft; moreover, it lacks its performative power. What remains is a play with convention, a play with rests, which itself can produce interesting artistic effects but does not carry proleptic qualities. Rosefeldt juxtaposed 60 manifestos into 12 collages but in spite of all, he did not propose his own one. Manifesto composed of manifestos does not offer any meta-manifesto or consolation.

The presented history of lack of Polish poetic manifestos after 1989 seems to be consonant with Rosefeldt's diagnosis. None of the aforementioned manifestos was a genuine tour de force; none of them lasted long enough to be considered to withstand the trial of time or to gain critical acclaim. The only manifesto of any import, Manifest Neolingwistyczny, has been after all declared to be a joke and a component of play among friends. One should also remember that the aforementioned manifestos were of an exceptional character, since there were almost no poetic manifestations of this form in the history of independent Poland.

Many scholars are hesitant about the unambiguous and definite perceiving the Polish post-1989 reality in terms of postmodernity and they have good reasons to do it. They prefer concepts of late modernity or liquid modernity, that reflect not only artistic tendencies but also changes in the cultural, economic and geopolitical landscape. Regardless of terminology and unaware of it, along with democracy came a cluster of new phenomena to which Polish literature is constantly trying to respond and to which the form of manifesto does not seem a valid answer.

\section{References}

Baran, M., Sendecki, M., Świetlicki, M. (1993). Wiersz wspólny (pólfinałowy). "BruLion" nr 21/22, p. 79.

Bromboszcz, R., Florek, M., Kopyt, S., Misiak, T., Podgórni, Ł. (2007). Manifest poezji cybernetycznej. "ProArte" nr 23, p. 42.

Cecko, M., Cyranowicz, M., Kasprzak, M., Lipszyc, J., Mueller, J. (2005). Manifest Neolingwistyczny v. 1.1 (2005). In: Gada!zabić? pa]n[tologia neolingwizmu. Red. M. Cyranowicz, P. Kozioł, oprac. graf. M. Sobczyk. Warszawa: Staromiejski Dom Kultury, pp. 158-159.

Cyranowicz, M., Dutkowski, R., Krauss, A., Lipszyc, J., Pakier, W., Słodownik, A. 
(2005). Meblowanie główww. In: Gada!zabić? pa]n[tologia neolingwizmu. Red. M. Cyranowicz, P. Kozioł, oprac. graf. M. Sobczyk. Warszawa: Staromiejski Dom Kultury, pp. 123-125.

Cyranowicz, M. [emce] (2005). [bez tytułu, komentarz do Manifest Neolingwistyczny v. 1.1]. In: Gada!zabić? pa]n[tologia neolingwizmu. Red. M. Cyranowicz, P. Kozioł, oprac. graf. M. Sobczyk. Warszawa: Staromiejski Dom Kultury, p. 158.

Czapliński, P. (1997). Poetyka manifestu literackiego 1918-1939. Warszawa: Instytut Badań Literackich.

Derrida, J. (1992). The other heading: reflections on today's Europe. Transl. by P.A. Brault and M.B. Naas, introduction by M.B. Naas. Bloomington - Indianapolis: Indiana University Press.

Fukuyama, F. (1992). The End of History and the Last Man. New York: Free Press. Gazda, G. (1987). Awangarda. Nowoczesność i tradycja. Łódź: Wydawnictwo Łódzkie. Głuszak, K., Kapela, J. (2005). Manifest protodupistyczny. In: Gada!zabić? pa]n[tologia neolingwizmu. Red. M. Cyranowicz, P. Kozioł, oprac. graf. M. Sobczyk. Warszawa: Staromiejski Dom Kultury, pp. 170-171.

Kasprzak, M. (2005). Nekrofest postneolingwistyczny. In: Gada!zabić? pa]n[tologia neolingwizmu. Red. M. Cyranowicz, P. Kozioł, oprac. graf. M. Sobczyk. Warszawa: Staromiejski Dom Kultury, pp. 9-10.

Kotuła, D. (2018). The Fall of the Hause of Users. The Bread Resolution's Narrative Shifts. "Tekstualia" nr 1 (4), pp. 109-124.

Mueller, J. (2005). Neolog [zamiast nekrologu]. In: Gada!zabić? pa]n[tologia neolingwizmu. Red. M. Cyranowicz, P. Kozioł, oprac. graf. M. Sobczyk. Warszawa: Staromiejski Dom Kultury, p. 8.

Onak, L., Podgórni, Ł. (2011). Manifest rozdzielczości chleba v. 1.7. "Rozdzieczość Chleba" nr 1, pp. 4-7.

Płucienniczak, P., Podgórni, Ł., Onak, L. (2015). "Nośnik" nr 3, pp. 38-55.

Puchner, M. (2006). Poetry and the Revolution: Marx, Manifestos and the Avant-Garde. Princeton, NJ: Princeton University Press.

Sienkiewicz, B. (2007). Poznawanie i nazywanie. Refleksja cywilizacyjna i epistemologiczna w polskiej poezji modernistycznej. Kraków: Universitas.

Śliz, A. (2015). Manifest literacki w Polsce: Kulturowa historia gatunku. [Niepublikowana rozprawa doktorska]. Łódź: Uniwersytet Łódzki.

Świetlicki, M. (2000). For Jan Polkowski. Transl. by W. Martin. "Chicago Review" no. 3-4, pp. 278-279.

Winkiel, L. (2015). Manifestos and Ars Poetica. In: The Routledge Companion to Experimental Literature. Ed. by J. Bray, A. Gibbons, B. McHale. London - New York: Routledge, pp. 253-266. 